\title{
Continuous Vocational Education of Employees in Conditions of Knowledge Economy: European Trends and Prospects of Ukraine
}

\author{
Olena Iastremska $^{1} \&$ Maryna Martynenko ${ }^{1}$ \\ ${ }^{1}$ Department of Economics, Organization and Planning of Enterprise Activity, Simon Kuznets Kharkiv National \\ University of Economics, Kharkiv, Ukraine \\ Correspondence: Maryna Martynenko, Department of Economics, Organization and Planning of Enterprise \\ Activity, Simon Kuznets Kharkiv National University of Economics, Kharkiv, Ukraine. E-mail: \\ mrnmartynenko@gmail.com
}

Received: April 7, 2015 Accepted: May 26, $2015 \quad$ Online Published: June 26, 2015

doi:10.5539/res.v7n11p89 URL: http://dx.doi.org/10.5539/res.v7n11p89

\begin{abstract}
One of the current trends in the world is formation of knowledge-based economies. A significant role in this process plays continuous vocational education and training of employees of enterprises as the main economic actors. The results of correlation analysis presented in the paper confirm the importance of on-the-job training and its interconnections with development of knowledge-based economy, competitiveness of the country and its economic growth. Considering Association Agreement between Ukraine and the European Union it is advisable to pay special attention to the peculiarities of vocational education and training in EU Member States. The complex study of the relationship between lifelong learning, on-the-job training, employment, development of the knowledge economy, economic growth and competitiveness within each country allows to divide the countries into two groups. This division was implemented according to correlation ties between the selected indicators. Taking into account the limited amount of funds spent on vocational education and training of employees at Ukrainian enterprises it is suggested to focus on creating organisational conditions for stimulating the development of self-education and professional self-improvement of employees. The establishment of the systems of organisational knowledge at enterprises is considered as the foundation for the development of such conditions.
\end{abstract}

Keywords: vocational education and training, European trends in vocational education, Ukraine, knowledge economy, system of organisational knowledge

\section{Introduction}

One of the major current trends in the countries of the world is the development of new types of economies-knowledge-based economies. By definition of Organisation for Economic Co-operation and Development (OECD, 1996) under such economies are understood "economies which are directly based on the production, distribution and use of knowledge and information". Production of knowledge plays a significant role in the given definition of the knowledge economy. There are other opinions on the nature of the knowledge economy. For example, Holubkin (2006) defines the knowledge economy as the stage of economic development which is characterized by the fact that knowledge and skills of employees, as well as those opportunities of organisations that are formed on their basis, play the most important role in the production and distribution.

As it was mentioned by Department of Trade \& Industry of Great Britain (1998) "the knowledge driven economy is not simply about strengthening the science base and raising the education and skill levels of the workforce. These objectives are vitally important and central to government policy. But success in the knowledge driven economy requires a shift in the business mind set: greater receptiveness to know-how and the ability to see its commercial potential; eagerness to keep on learning at all levels in a business; and flair in spotting new customer needs and fresh business opportunities". This definition emphasizes the important role of business in creating a knowledge economy. It is noted that the main driving force of economic development based on knowledge is a skilled labour force. That is the level of education and professionalism of modern workers depends largely on the effectiveness of creation of new innovative knowledge and their practical implementation in the activity of economic entities. This, in its turn, forms the basis for the economic effects at all levels - not only at the level of individual enterprise but also at the level of the industry and the country as a 
whole.

The general level of education of population and continuous adult education is important for the formation of the social context of positive attitude to the role of education in social and economic development of the country. However, considering the connection of education with the country's competitiveness in the global space, it is advisable to pay special attention to the continuous vocational education and training (VET) of employees of enterprises as the main economic actors. The problems of improvement of vocational education were studied by such modern Ukrainian scientists as Beztelesna (2012), Hnibidenko (2008), Makarova (2014), Savchenko (2012). Various aspects of vocational education of adults and lifelong learning were considered in the works of the researchers Boutsiouki (2014); Buiskool, Van Lakerveld and Broek (2009); Chirkina (2015); Figel (2009); Mulder, Weigel and Collins (2007). The works of Buckman (2004); Garvin (2003); Huber (1991); Senge, Lucas and Smith (2000); Tsang (1997) deserve special attention because they reveal the content and peculiarities of organisational learning which is the key component of the lifelong learning.

The purpose of the paper is detection of the peculiarities of vocational education in the EU Member States and Ukraine and development of recommendations for continuous vocational training of employees in the conditions of knowledge economy.

\section{Material Studied and Methods}

Ukraine has chosen the European vector of development. And the Association Agreement between Ukraine and the European Union was signed. It is advisable to pay special attention to the comparative analysis of the condition of the knowledge economy in Ukraine and EU Member States, as well as determining the peculiarities of organisation of vocational training of employees in this context. Information basis for the study was made with the statistical reporting data on VET of such international resources as Eurostat, Eurofound, CEDEFOP, UNESCO and others. The data on the dynamics of the Knowledge Economy Index (KEI) in various European countries were received from the provided by the World Bank information resource dedicated to the Knowledge Assessment Methodology (World Bank Group, 2012. Knowledge Assessment Methodology 2012). According to this methodology the KEI is constructed as the simple average of 12 variables (score indicators). These indicators are integrated in 4 groupes according to the four knowledge economy pillars: economic and institutional regime, innovation system, education, information and communication technologies. The first group includes indicators of Tariff \& Nontariff Barriers, Regulatory Quality, Rule of Law. On the basis of these indicators the Economic and Institutional Regime Subindex (ERS) is calculated. The indicators of the second group are Royalty and License Fees Payments and Receipts, Patent Applications Granted by the USPatent and Trademark Office, Scientific and Technical Journal Articles. They compose the Innovation Subindex (INS). The Education Subindex (ES) is built on the basis of the indicators of the third group, such as Average Years of Schooling, Secondary Enrollment, Tertiary Enrollment. And the indicators of the fourth group-Telephones per 1,000 people, Computers per 1,000 people, Internet Users per 10,000 people - are included in Information and Communication Technologies Subindex (ICTS). The simple average of INS, ES and ICTS is Knowledge Index (KI). For substantiation of the interconnection between indicators of the state of the knowledge economy and VET in European countries we used the methods of correlation, cluster and discriminant analysis, implemented by means of software package Statistica 10.0 .

\section{Results}

For the purpose of evaluation and comparative analysis of the level of development of the knowledge economy in various countries, the World Bank has developed and implemented Knowledge Assessment Methodology (World Bank Group, 2012. Knowledge Assessment Methodology 2012). This methodology provides for the possibility of definition of the KEI and KI and four subindexes as well, which are used as a basis for calculation of the mentioned integrated indexes. To date, this methodology has been generally accepted and widely used in the world.

To further demonstrate graphically the dynamics of KEI, KI and their subindexes, it is appropriate to limit oneself to a certain number of EU Member States. So, according to the rating of KEI in 2012 year among countries that are considered to be old Member States, the first two places went to Sweden and Finland and the last two places in the same group - to Portugal and Greece. Among the countries - new EU Member States the first two positions by the KEI rating belong to Estonia and the Czech Republic. The last places went to Romania and Bulgaria. So, choosing the four countries from each group of new and old EU Member States, the paper presents the directions of changes of the above mentioned indices for the period from 1995 to 2012 which are given in the Table 1. 
Table 1. Directions of changes of KEI / KI and its subindexes by years

\begin{tabular}{ccccccccccccccccccccc}
\hline Country & \multicolumn{1}{c}{ 1995 - 2000 } & \multicolumn{1}{c}{ 2000 - 2008 } & \multicolumn{1}{c}{ 2008-2012 } \\
& KEI & KI & ERS & INS & ES & ICTS & KEI & KI & ERS & INS & ES & ICTS & KEI & KI & ERS & INS & ES & ICTS \\
\hline Sweden & $\uparrow$ & $\uparrow$ & $\downarrow$ & $\downarrow$ & $\uparrow$ & $\uparrow$ & $\downarrow$ & $\downarrow$ & $\uparrow$ & $\uparrow$ & $\downarrow$ & $\uparrow$ & $\downarrow$ & $\downarrow$ & $\uparrow$ & $\downarrow$ & $\downarrow$ & $\downarrow$ \\
Finland & $\downarrow$ & $\downarrow$ & $\uparrow$ & $\uparrow$ & $\downarrow$ & $\downarrow$ & $\uparrow$ & $\uparrow$ & $\downarrow$ & $\downarrow$ & $\uparrow$ & $\downarrow$ & $\downarrow$ & $\downarrow$ & $\uparrow$ & $\uparrow$ & $\downarrow$ & $\uparrow$ \\
Portugal & $\downarrow$ & $\downarrow$ & $\downarrow$ & $\uparrow$ & $\downarrow$ & $\downarrow$ & $\downarrow$ & $\downarrow$ & $\uparrow$ & $\downarrow$ & $\downarrow$ & $\downarrow$ & $\uparrow$ & $\uparrow$ & $\downarrow$ & $\uparrow$ & $\uparrow$ & $\downarrow$ \\
Greece & $\downarrow$ & $\downarrow$ & $\downarrow$ & $\uparrow$ & $\downarrow$ & $\downarrow$ & $\downarrow$ & $\downarrow$ & $\downarrow$ & $\downarrow$ & $\uparrow$ & $\downarrow$ & $\uparrow$ & $\uparrow$ & $\downarrow$ & $\uparrow$ & $\uparrow$ & $\downarrow$ \\
Estonia & $\uparrow$ & $\uparrow$ & $\uparrow$ & $\uparrow$ & $\uparrow$ & $\downarrow$ & $\uparrow$ & $\uparrow$ & $\uparrow$ & $\uparrow$ & $\downarrow$ & $\uparrow$ & $\uparrow$ & $\uparrow$ & $\uparrow$ & $\uparrow$ & $\uparrow$ & $\downarrow$ \\
Czech & $\downarrow$ & $\uparrow$ & $\downarrow$ & $\uparrow$ & $\uparrow$ & $\downarrow$ & $\uparrow$ & $\uparrow$ & $\uparrow$ & $\uparrow$ & $\uparrow$ & $\uparrow$ & $\uparrow$ & $\uparrow$ & $\uparrow$ & $\uparrow$ & $\uparrow$ & $\uparrow$ \\
Republic & & & & & & & $\uparrow$ & $\uparrow$ & $\uparrow$ & $\uparrow$ & $\uparrow$ & $\uparrow$ & $\uparrow$ & $\uparrow$ & $\uparrow$ & $\uparrow$ & & $\uparrow$ \\
Romania & $\uparrow$ & $\uparrow$ & $\downarrow$ & $\uparrow$ & $\uparrow$ & $\uparrow$ & $\uparrow$ & $\uparrow$ & $\uparrow$ & $\uparrow$ & $\downarrow$ & $\uparrow$ & $\uparrow$ & $\uparrow$ & $\uparrow$ & $\uparrow$ & $\uparrow$ & $\uparrow$ \\
Bulgaria & $\downarrow$ & $\downarrow$ & $\downarrow$ & $\downarrow$ & $\uparrow$ & $\downarrow$ & $\uparrow$ & $\uparrow$ & $\uparrow$ & $\uparrow$ & $\uparrow$ & $\downarrow$ & $\uparrow$ & $\downarrow$ & $\uparrow$ & $\uparrow$ & $\downarrow$ & $\uparrow$ \\
\hline
\end{tabular}

Note. The data were obtained from: World Bank Group, 2012. KEI and KI Indexes 2012

As we see from Table 1 in $79 \%$ of cases the direction of change of the KEI and the KI coincides with the direction of changes of ES. As for the other components, the percentage of coincidence of directions of change of indexes is considerably smaller. In $67 \%$ of cases for the studied countries the directions of change of KEI and KI coincide with the direction of changes of INS and ICTS and only in $50 \%$ of cases the directions of changes of ERS coincide with KI (and in 58\% of cases with KEI). When making the simplest comparison of the dynamics of KEI and KI and their components it can be noted that education is the sphere the development of which largely determines the state of the knowledge economy in the majority of the EU Member States selected for the study. However, in Ukraine we can observe a different regularity as shown in Figure 1.

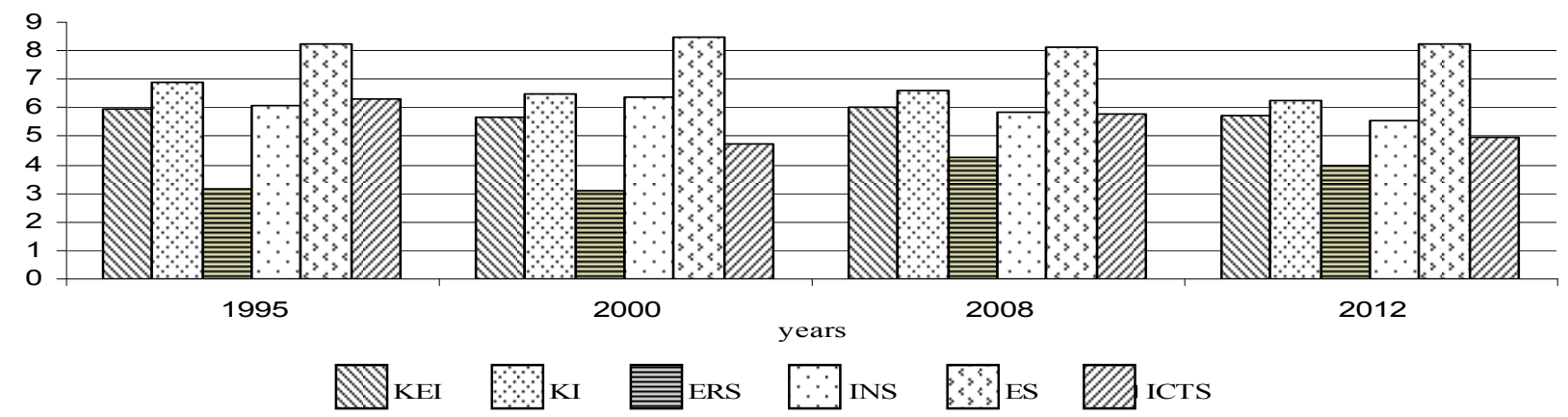

Figure 1. Dynamics of values of KEI, KI and their subindexes for Ukraine

Note. The data were obtained from: World Bank Group, 2012. KEI and KI Indexes 2012. Indexes and subindexes: KEI-Knowledge Economy Index, KI-Knowledge Index, ERS—Economic Regime Subindex, INS-Innovation Subindex, ES-Education Subindex, ICTS-Information and Communication Technology Subindex

As we see in the figure, the directions of change of the KEI and KI are opposite to directions of changes of ES in Ukraine. In 2012 in Ukraine ES was 8, 26, which is higher than in Romania (7.55), Bulgaria (6.25) and Portugal (6.99). However, the KEI in these countries is higher than in Ukraine. As it is given in (The World Bank Group, 2012. Knowledge Assessment Methodology), the first step in building a national knowledge economy is to understand your country's strengths and weaknesses, as well as the strengths and the weaknesses of actual and potential competitors. 
For a better understanding of the reasons of opposite dynamics in the KEI and ES it is necessary to conduct further analysis of the content of the latter. Considering the structure of ES one should pay attention to the fact that the given subindex is calculated on the basis of three score indicators (The World Bank Group, 2012. Knowledge Assessment Methodology):

- Adult Literacy Rate (it is the percentage of people ages 15 and above who can, with understanding, read and write a short, simple statement on their everyday life, \%);

- Secondary Enrollment (the ratio of total secondary enrollment, regardless of age, to the population of the age group that officially corresponds to the level of education shown, \%);

- Tertiary Enrollment (the ratio of total tertiary enrollment, regardless of age, to the population of the age group that officially corresponds to the level of education shown, \%).

Herewith, the selected indicators reflect the level of education of the population over 15 due to the predominant significance of education of adults in the formation of knowledge economy. It should be noted that in the given above definitions of the knowledge economy emphasis is made on the significant role of not only theoretical but also practical knowledge which is formed directly in the process of working activity. Analysing the basic indicators used to calculate the ES, it is important to accentuate that they certainly characterize the potential of society to create knowledge economy. They do not reflect the results of realisation of this potential. Ukraine is a striking example of a country that has high educational potential, but its implementation is unfortunately constrained by significant institutional barriers as evidenced by the low value of the ERS (the lowest of four subindexes).

The implementation of the educational potential of any country depends heavily on the extent to which educational programs and plans meet the requirements of the labour market and prospects of development of branches of economy. One of the reasons that in Ukraine there is no direct relationship of cause and effect between the level of formal secondary and higher education and the level of economic development of the country is the acceleration of knowledge updating. The latter can be described quantitatively by half-life of competence by which we understand the period of time during which the previously acquired knowledge and professional experience are losing relevance or they are reduced by half.

Today, we have even the half-life of competence established for certain types of knowledge. For example, it is believed that this period in industrial production makes an average of 0.5 years, in high tech-2.25 years, in banking and public administration — 5 years (Zhdankin, 2009; Hin, 2007; Dovbii, 2009; Nemtzev \& Mahmudova, 2012). The existing in our country system of educational standards does not have time to rebuild with adequate speed according to the above given terms. So, often there is a situation in which, even under conditions of quality education with a significant percentage of the population covered by it, competences acquired in the formal education system quickly lose relevance. Given the accelerated rate of renewal of knowledge in all sectors of the economy, it can be affirmed that the key principles of the further development of adult education is its continuity and maximum approach to the needs of production.

The principle of continuity of education was declared in the Memorandum of Lifelong Learning signed by the Member States in 2000 where there are six key priorities in education, namely:

- Guarantee universal and continuing access to learning for gaining and renewing the skills needed for sustained participation in the knowledge society;

- visibly raise levels of investment in human resources in order to place priority on Europe's most important asset - its people;

- Develop effective teaching and learning methods and contexts for the continuum of lifelong and lifewide learning;

- Significantly improve the ways in which learning participation and outcomes are understood and appreciated, particularly non-formal and informal learning;

- Ensure that everyone can easily access good quality information and advice about learning opportunities throughout Europe and throughout their lives;

- Provide lifelong learning opportunities as close to learners as possible, in their own communities and supported through ICT-based facilities wherever appropriate (Commission of the European Communities, 2000).

Adherence to the principle of maximum approximation of education to production needs can be achieved by improving such an important part of education as an continuous vocational education and on-the-job training of employees as its main element. This is the part of education which provides the approximation of professional 
competencies of employees to the needs of the labour market in the short term. This contributes to the increase of competitiveness of the country.

To test the latter assertion it is useful to analyze whether there is relationship between the intensity of the vocational training of employees in the workplace, development of the knowledge economy and competitiveness of the country. As the identifiers we take the indicators On-the-job training (OJT), the KEI / KI and Global Competitiveness Index (GCI), which are calculated for the countries of the world by the World Bank and the World Economic Forum (World Bank Institute, 2008, World Economic Forum, 2014). In addition we shall trace the dynamics of such indicators as Gross Domestic Product per capita (GDP p. c.) and Lifelong Learning (LLL). The rate of changes of GDP p. c. makes it possible to make conclusions about economic growth of the countries (World Bank, 2015. GDP per capita). LLL shows the percentage of each country's population aged 25 - 64 years old, who confirmed that they were learning or upgrading their qualification within the period of four weeks preceding the survey (Eurostat, 2015. Lifelong Learning Eurostat Database). This indicator is the part of the study of EU Labour Force Survey. Websites of the Eurostat (LLL), the World Economic Forum (GCI and OJT) as well as the World Bank (KEI / KI, GDP p.c) were chosen as the sources of statistical information .

For accomplishment of the task the correlation analysis method was used, implemented by means of software package Statistica 10.0. There was made an analysis of the values of the above given indicators for the period of 1995-2014 years for the EU Member States and Ukraine. The results of the correlation analysis are shown in Figure 2.

There was established the presence of statistically significant correlations $(\mathrm{p}<0.05)$ at: 0.93 for GCI- OnJT; 0.92 for GCI- KEI; 0.91 for GCI- KI; 0.75 for GDP p.c.- KEI; 0.72 for GDP p.c.- GCI; 0.86 for OJT- KEI; 0.85 for OnJT- KI; 0.96 for KEI - KI (the last two indexes differ in only one subindex, since the calculation KEI takes into consideration the same subindexes as in the calculation of KI but additionally takes into consideration the IRS, so this correlation is caused by these very reasons).

\begin{tabular}{|c|c|c|c|c|c|c||}
\hline \hline & GCI & $\begin{array}{c}\text { GDP p. } \\
\text { c. }\end{array}$ & OJT & LLL & KEI & KI \\
\hline \hline GCI & 1.00 & 0.72 & 0.93 & 0.74 & 0.92 & 0.91 \\
\hline \hline $\begin{array}{c}\text { GDP p. } \\
\text { c. }\end{array}$ & 0.72 & 1.00 & 0.65 & 0.5 & 0.75 & 0.67 \\
\hline \hline OJT & 0.93 & 0.65 & 1.00 & 0.59 & 0.86 & 0.85 \\
\hline \hline LLL & 0.74 & 0.5 & 0.59 & 1.00 & 0.76 & 0.74 \\
\hline \hline KEI & 0.92 & 0.75 & 0.86 & 0.76 & 1.00 & 0.96 \\
\hline \hline KI & 0.91 & 0.67 & 0.85 & 0.74 & 0.96 & 1.00 \\
\hline
\end{tabular}

Figure 2. The results of the correlation analysis of dynamics of indicators (GCI, GDP p.c., OJT, LLL, KEI, KI) in EU Member States and Ukraine

As it can be seen from the results of correlation analysis, there is a significant positive correlation between the GCI, KEI / KI and OJT even in the countries where the change trends of KEI and ES do not match. This again confirms the paramount importance of vocational training in the workplace. It is an integral part of continuous VET of the adult population that is recognised by all major European countries. The latter explains the attention given to this type of education in the studies conducted on a regular basis both in the world and separately for the EU Member States. Among the major information resources dedicated to the problems of continuous vocational education and adult education, we should note CVTS (Continuing Vocational Training Survey), EU LFS (EU Labour Force Survey), EU LCS (EU Labour Cost Survey), UOE (Unesco / OECD / Eurostat statistics collection), ESSPROS (European system on social protection on statistics), AES (Adult Education Survey), CIS (Community Innovation Surveys), Education at a Glance, EWCS (European Working Conditions Survey) and others. However, the state of continuous vocational training within enterprises is not covered by all of these resources. The most complete list of indicators highlighting the participation of enterprises in vocational training of workers is represented in CVTS (Eurostat, 2010). LFS contains the section about education and training 
where there is little information about the most recent learning activity during paid working hours (Eurostat, 2015. European Union Labour Force Survey). Such indicator as Vocational Training Expenditures in the structure of labour costs of enterprises is a part of LCS (Eurostat, 2015. Labour Market Statistics. Labour Cost Surveys). CIS contains such indicator as Training for Innovative Activities (training for personnel specifically for the development of new or significantly improved products and processes) (Eurostat, 2015. Science and Technology Statistics. Community Innovation Survey). There is such indicator as Employer-Sponsored Learning Activities (paid at least partially by the employer and/or done during paid working hours) within AES (Eurostat, 2015. Adult Education Survey). One of the topics of Enterprise surveys is workforce. This topic includes such indicators: percent of firms offering formal training; proportion of workers offered formal training (World Bank Group, 2015). The information about participation of employees in employer-paid training and on-the-job training, about the influence of training on improving ways of work and its security, about ratio of reguested and provided employee-paid training is represented in EWCS (Eurofound, 2015). Such resource as "On the way to 2020: data for VET policies" contains indicators from CVTS and from EWCS (Cedefop, 2013). Qualitative data on training at enterprises could be received from World TVET Database (UNESCO-UNEVOC, 2015).

Thus, the most completely and comprehensivly state of CVT at enterprises is highlighted by CVTS that is conducted for the EU Member States every 5 years since 1995. Unfortunately, the composition of the participating countries of this study is not constant for various reasons. Therefore, further focus is mainly given to those European countries that participated in this study since the first stages. It is done for better coverage of the dynamics of the main indicators of this review. The key indicators are as follows:

- Incidence (training enterprises providing any type of CVT in all enterprises, \%);

- Participation (employees in all enterprises participating in CVT courses, \%);

- Intensity (total number of hours of CVT courses in the total number of hours worked by all employees in all enterprises (per 1000 hours worked));

- Total monetary expenditure (total costs of CVT courses in total labour costs of all enterprises, \%) (Cedefop, 2010).

Unfortunately, it is difficult to find indicators in the Ukrainian statistics that would fully coincide with the given above by content. We may take as an analogue of the indicator "participation" the number of employees who received professional training and professional development in relation to the registered number of staff.

As an analogue of the indicator of "total monetary expenditure" may be the ratio of the training costs to total labour costs. Figures 3 and 4 show the mentioned indicators for some European countries that participated in the survey CVTS and similar indicators for Ukraine in 2010 (the latest data on research CVTS4 is available so far).

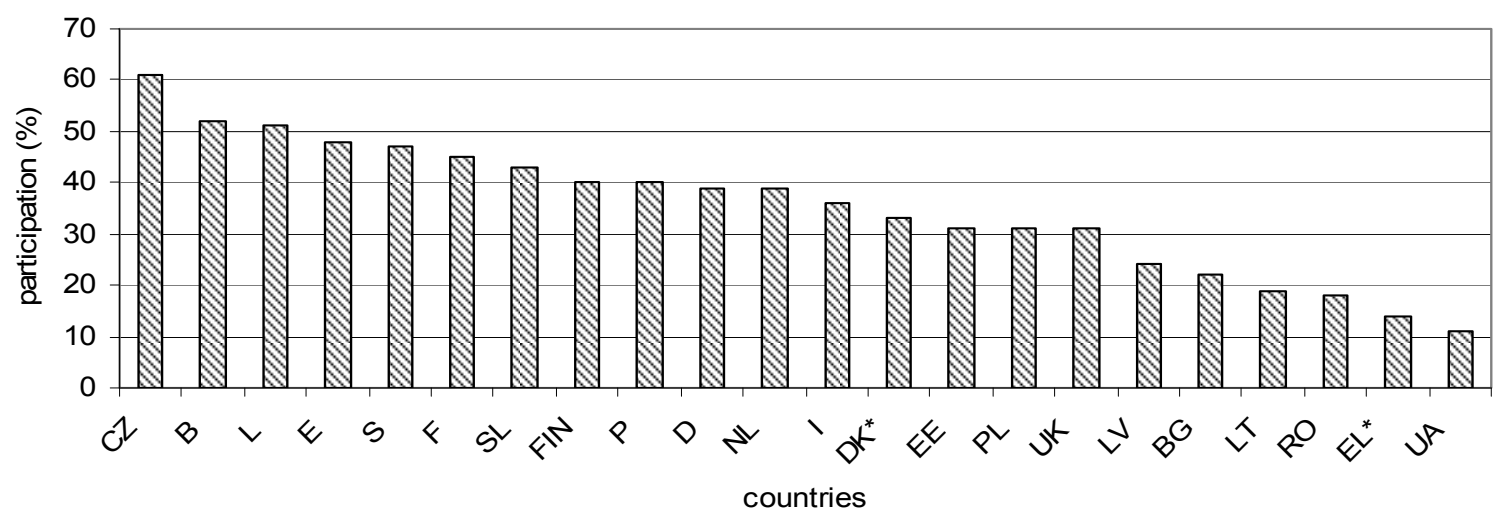

Figure 3. Participation of employees in CVT courses in some EU Member States and Ukraine in 2010 year

Note. The data were obtained from: Knoema, Eurostat (2015) and The State Service of Statistics of Ukraine (2011). Countries: B-Belgium, BG-Bulgaria, CZ - Czech Republic, D-Germany, DK*_Denmark (data on 2005 year), E-Spain, EE-Estonia, EL*_Greece (data on 2005 year), F-France, FIN-Finland, I-Italy, L-Luxembourg, LT-Lithuania, LV-Latvia, NL-The Netherlands, P-Portugal, PL-Poland, RO-Romania, S—Sweden, Sl—Slovenia, UA-Ukraine, UK—United Kingdom. 


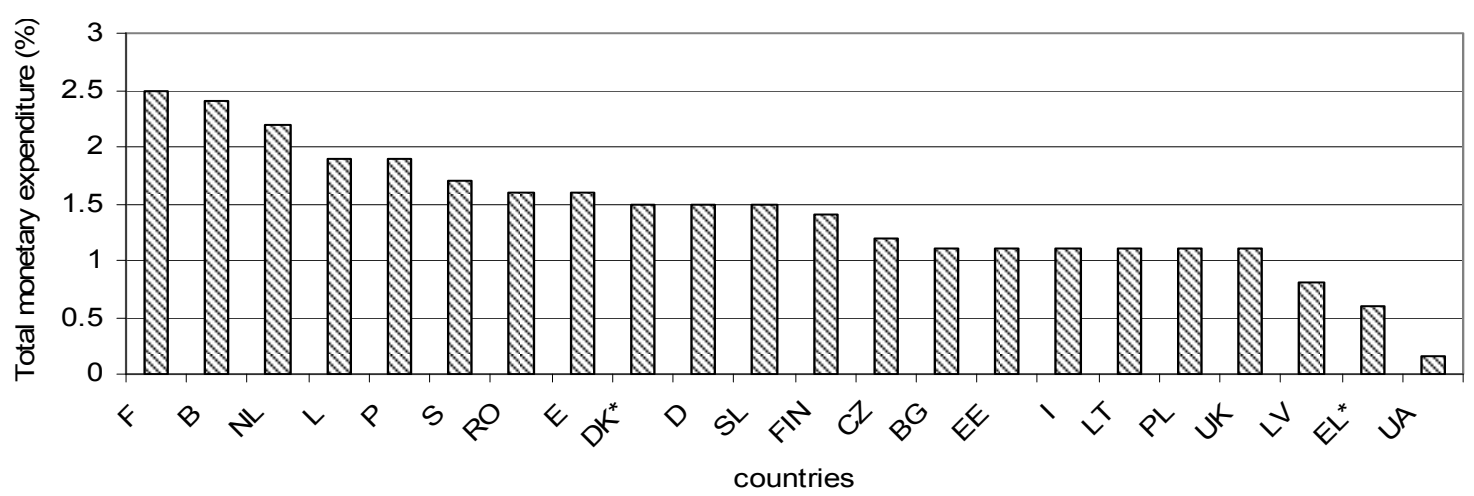

Figure 4. Total costs of CVT courses in total labour costs of enterprises in some EU Member States and Ukraine in 2010 year

Note. The data were obtained from: Knoema, Eurostat (2015) and The State Service of Statistics of Ukraine (2011).

* data on 2005 year.

As it can be seen in the given Figures 3 and 4 Ukraine should pay more attention to vocational training of employees, which is one of the most important components of continuous vocational education.

To better understand the relationship between the lifelong learning, on-the-job training, employment, development of the knowledge economy, competitiveness of the country and its economic grouth, the following indicators were chosen: LLL, OJT, Emp (employment), KEI / KI and its subindexes, GCI and GDP p. c.

The correlation ties between selected indicators with the use of correlation analysis were studied within each country. This means that correlation matrix was constructed for each individual country. We took into account only statistically reliable $(\mathrm{p}<0.05)$ values (correlation coefficient value is over 0.7$)$ of correlation. From further statistical analysis there were excluded: one of the duplicating correlations (e.g., from two variables KEI-ES and KI-ES we left KI-ES as the one that contains more significant values); variables excluded by the method of principal components as such that are trivially one in another, for example, KEI-KI. After the construction of the correlation matrix for each of the countries under study there was used the method of cluster analysis. It was used to identify those or other regularities in the correlation ties between the given above indicators and integration of the countries under study into groups. Figure 5 shows a classification tree that allows to visualize the obtained results of cluster analysis.

Figure 5 shows that we can distinguish two groups of countries. The first group includes Belgium, Luxembourg, France, Great Britain, Denmark, Portugal, Sweden, Greece, Slovenia, Finland, Germany, Italy and the Netherlands. The second group includes Bulgaria, Poland, Czech Republic, Estonia, Romania, Spain, Latvia, Lithuania and Ukraine. Besides, we can distinguish additional subgroups in each group, for example, Belgium, Luxembourg, France, Great Britain - in the first group or Latvia, Lithuania, Ukraine - in the second and so on. 


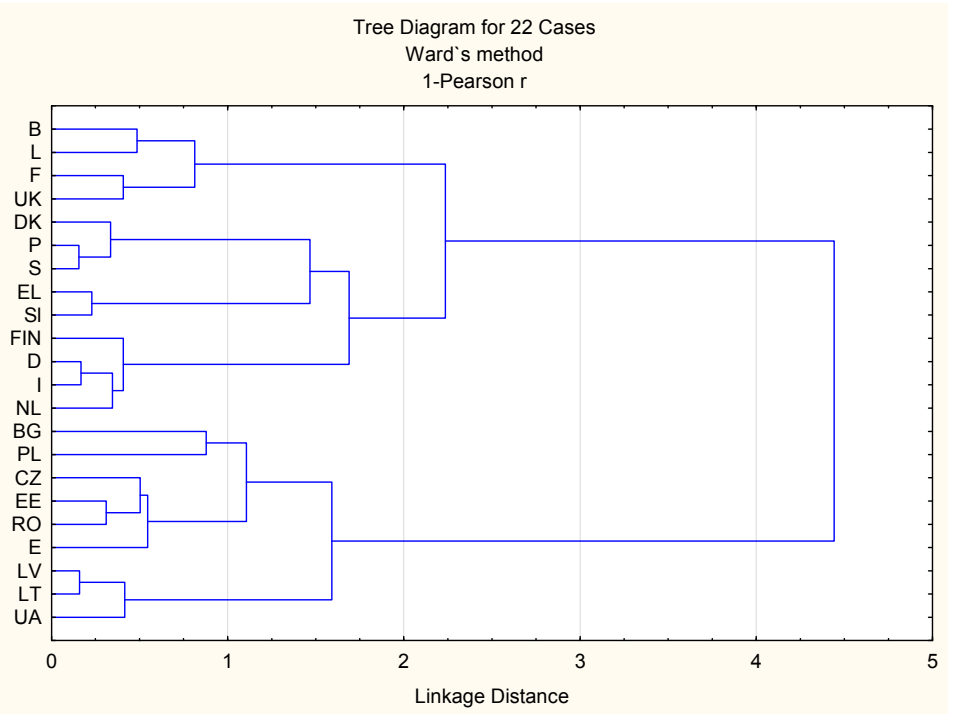

Figure 5. The results of cluster analysis of the correlation ties between indicators (LLL, OJT, Emp, KEI / KI and its subindexes, GCI and GDP p. c.) for EU Member States and Ukraine

To confirm the adequacy of the obtained classification was used the discriminant analysis which proved the high quality of the classification: Wilks lambda 0.076 ; approx. F $(9,11)=14.80 ; \mathrm{p}<0.0001$. We received a classification function that with the probability of $99.92 \%$ allows distinguishing the above mentioned two groups. The components of this function are shown in Figure 6.

\begin{tabular}{|r|r|r|}
\hline \multicolumn{3}{|c|}{ Classification Function } \\
\hline \hline & G_1:1 & G_2:2 \\
\hline \hline OJT-GCI & 1.52 & 1.69 \\
\hline \hline GDP p.c.-LLL & 6.51 & -0.62 \\
\hline \hline GDP p.c.-Emp & 9.17 & 1.53 \\
\hline \hline LLL-Emp & 0.09 & 11.47 \\
\hline \hline GCI-Emp & 0.32 & 0.63 \\
\hline \hline KI-ES & 13.44 & -3.68 \\
\hline \hline KEI-ERS & 5.99 & 12.76 \\
\hline KI-INS & -11.9 & 26.74 \\
\hline \hline KI-ICTS & 1.83 & 7.29 \\
\hline Constant & -11.2 & -19.4 \\
\hline
\end{tabular}

Figure 6. Components of the classification function that determines whether the country belongs to the first or second group

The values of the coefficients of the given classification function show that the most significant elements of the function by which we can determine the belonging of the country to the first group is KI-ES, GDP p.c.-Emp and GDP p.c.-LLL, and the least significant for the first group are KI-INS and LLL- Emp. In its turn, the most important classification variables that determine the belonging to the second group are KI-INS, KEI-ERS and 
LLL-Emp and the least significant ones for the second group are KI-ES and GDP pc-LLL.

For a more thorough determination of the reasons for this differentiation of the countries in the above given groups it is appropriate to use qualitative analysis of the issues related to the organisation of VET in these countries. The source of information for qualitative analysis there were chosen reports on Cedefop site that provide expanded description of peculiarities of VET in various countries (Cedefop, 2015). The greatest interest for this study presents information on the specifics of organisation of vocational training at enterprises, as well as to the degree of practical orientation of the systems of VET of the countries surveyed.

The prevailing focus on the needs of the labour market in the process of vocational education and training of employees is the characteristic feature of the countries included in the first group. For example, in Luxembourg, all the programs and plans are very closely and directly linked to labour market requirements. Skills received by the learners are in strict accordance with the needs of enterprises. The special feature of the operation of vocational education establishments in Finland is also a close interaction with the labour market although a very small proportion of providers of vocational training is outside regulated by the government sector. Unlike Finland, Belgium's vocational education system is more decentralized but there is a close interaction of social partners with organisations and institutions that organize vocational training. In France, the government has a special central budget to finance subsidies for the development and implementation of plans of vocational training at enterprises and organisations and locally provides mandatory for every employer financing of vocational training of their employees. In Germany, there is a significant number of collective agreements in various fields of activity. They regulate the provision of services of vocational training of workers. Danish law provides for all employers' contributions to the specially created compensation fund and annual contributions for each employee who works under conditions of full employment. Money from these funds are used to finance higher secondary education and training, continuous vocational adult education, and to support those companies that are involved in teaching students. The issue of education in the workplace in Sweden has always been governed by specific agreements between labour market actors at both the national and local level. There is also the financial government's support of enterprises that conduct professional training of managers and mechanisms of tax cuts for this sort of firms. In most countries of the first group, regardless of the degree of centralisation of vocational education and training, much attention is paid to the coordination of educational programs and plans with the requirements of the labour market. This may explain the central role of correlation of ES with KEI / KI. In this case, the knowledge created in the system of education, especially vocational education, has a clear practical orientation. The latter determines the presence of a positive relationship between the dynamics of employment level and lifelong learning with the dynamics of GDP per capita.

The majority of the countries included in the second group belong to the new members of EU. Each of these countries has certain peculiar characteristics of organisation of VET of employees. For example, in Latvia vocational training of employees of enterprises is optional, at the same time, all the costs of training of employees, if it is done, is covered only by employers. The tax system also discourages the latter to invest in the vocational training of employees. The continuous vocational training of workers in Lithuania is also predominantly funded by enterprises or paid for by learners. In addition to that, any enterprise that has received the appropriate license from the Ministry of Education of the country can be the provider of formal services of vocational education and training. However, more often enterprises use informal ways of training employees in the workplace. The peculiarities of the approach to vocational training in the workplace in Bulgaria lies in the fact that there are no specific regulations or other regulating legal documents that would legitimise the skills and knowledge gained through informal learning in the workplace. The role of employers in shaping curricula and programs is not very active and is defined as the possibility of their participation in the process of examination tests for acquiring professional competences. Vocational training of employees of enterprises in the Czech Republic is not the subject for state regulation and obtained after such training certificates are valid only within the enterprise which organised this training. The funding of this training is provided mainly by the employer. In Poland training at enterprises also belongs to informal vocational training. There is even a Polish Agency for Enterprise Development financed by European funds. It offers various kinds of professional training for employees, but, unfortunately, it is not very popular among employers. On the one hand, the significant correlation ties, characteristic for the second group of countries, between lifelong learning and employment level can be explained by the increasing role of education of a person as its competitive advantage in the job market. On the other hand, there is not very significant correlation weight of ES with KEI / KI in classification function. It is explained by the fact that despite the high values of ES in some countries (such as Ukraine) the issues of coordination of the market of education services and labour market are not fully resolved. There was detected significant correlation between INS, ERS and KEI / KI in the countries of the second group. It indicates that 
institutional changes in the field of vocational education and its innovative orientation may be those directions within which it is advisable to focus further measures to promote VET. Especially the latter is important for Ukraine as the country with a very low ERS.

There are certain prerequisites for institutional changes in the field of VET in Ukraine. Vocational training of employees in Ukraine is regulated by a number of regulatory acts. Thus, the Labour Code of Ukraine provides the privileges for employees who combine work with studies (Verkhovna Rada [VR] of Ukraine, 2015. The Labour Code of Ukraine). According to the Law of Ukraine "On Education", the self-education and postgraduate education in the form of vocational education of employees are singled out in the structure among other types (VR of Ukraine, 2015. On Education). These are the components in the structure of education which have the direct relation to learning throughout the entire working career and that's why they deserve special attention within the limits of this research. We can view the anticipated by the Law of Ukraine "On Employment of Population" expansion of possibilities for increase of competitiveness of the people older than 45 which is supported by the Resolution of the Cabinet of Ministers of Ukraine, dated 03.20.2013, No. 207 (Cabinet of Ministers of Ukraine, 2014). This very Law also states the right of every citizen for vocational education "which is realised by way of initial vocational training, re-training, specialization and advanced training, probation period at vocational training schools, institutions of higher education and postgraduate education institutions, directly at working places in various industries or service sector with the purpose of obtaining the corresponding qualification or bringing its level in accordance with the requirements of modern production or service sector"(VR of Ukraine, 2015. On Employment of Population). The realisation of this right by employees depends on many factors. Among them, besides personal motivation for education and taking the responsibility for one's own future, the introduction of the procedures of official confirmation of those competences with corresponding documents, obtained by a person not only as a result of formal but other types of vocational education. So, there must exist mechanisms of assessment and acknowledgement of the results of informal education.

We should single out the Resolution of the Cabinet of Ministers of Ukraine, dated 05.15.2013, No. 340, among the basic regulatory documents, which to some extent provide for the possibility of such acknowledgement. This document approves the Order of confirmation of results of informal vocational training of people of working professions (Cabinet of Ministers of Ukraine, 2013). There is also the Law of Ukraine "On Professional Development of Employees" which defines informal vocational education as "acquiring of professional knowledge, skills and habits by the employees not regulated by the place of acquiring, period and form of education" and also says that such education of employees " is done with their consent immediately at the employer's place according to the employer's decision, at his expense with the account of the requirements of his economic or other activity" (VR of Ukraine, 2013). Thus, at present, the informal vocational education is acknowledged in Ukraine at legislative level as the type of vocational education but there are still many problems as to taking into account the requirements of the work of businesses, about which it goes in the Law, in the process of vocational education. The development and introduction of the system of professional standards is the important precondition of vocational education adaptation to the requirements of employers. According to the amendments to the Law of Ukraine "On Vocational Education" by professional standards we should understand "approved in the established order requirements to the qualification of employees, their competencies that are determined by employers and serve as a basis for formation of professional qualifications" (VR of Ukraine, 2015. On Vocational Education). Therefore, the requirements formulated by employers are of the fist priority importance in formation of professional standards as a basis of vocational education. The more definite and adequate as to the modern tendencies in the labour market will be these requirements, the more efficient will be the system of vocational education, which will take the mentioned professional standards as a basis. The definite formulation of the requirements by employers is possible in the case when employers do not stand back from the process of vocational education but take an active part in it.

\section{Discussion}

In conditions of the limited amount of funds spent on VET of employees by business it is expedient for Ukrainian enterprises to focus on creating organisational conditions. Organisational conditions would stimulate the development of self-education and professional self-improvement, building the foundation for the development of non-formal education. The combination of non-formal education with performance of work tasks proved to be highly effective in developed European countries. One way of forming such condition is the establishment of the systems of organisational knowledge at enterprises. Under the system of organisational knowledge we suggest to understand a set of organisational knowledge related to personalized (individual employees, work teams, groups and teams, professional communities) and personalized (corporate information 
systems, databases, hardware and software, all types of documents) carriers and their relationships as well. The importance of organisational knowledge for continuous vocational training of employees under conditions of limited resources for its additional funding is as follows:

Firstly, organisational knowledge is the basis of organisational competencies and therefore have extremely practical orientation. They focus on achieving organisational goals. In its turn, organisational competences may act as a guideline in the process of organising and conducting vocational training and upgrading of employees' qualification as they define the areas of development of vocational knowledge that are important for a particular enterprise;

Secondly, the functioning of the system of organisational knowledge will contribute to formation of clear understanding among employers of the competencies of employees who determine competitiveness of an enterprise. In the process of participation in the development of professional standards, employers can reasonably articulate those requirements which must be set for modern professionals. Orientation of vocational education for such professional standards in the development of educational programs and plans will allow the coordination of the results of its operation with the requirements of labour market;

Thirdly, the rate of renewal of practical knowledge in various fields of activity usually exceeds the rate of updating of training programs in the field of vocational education. As a result one can observe failing of the system of formal vocational training to keep up with the requirements of the labour market. Functioning of the system of organisational knowledge and its integration into the process of continuous VET will contribute to immediate delivery of new knowledge created in the process of enterprise operation to those employees who need this knowledge the most and thus accelerate bringing their competencies in line with the requirements of the labour market.

Thus, the formation of organisational knowledge of modern Ukrainian enterprises is a promising direction of creating organisational conditions for continuous vocational training of employees on the basis of building learning organisations.

\section{Conclusions}

An integral condition for the formation and development of knowledge-based economies in European countries is an improvement of VET to ensure their continuity and correspondence to the requirements of the labour market.

An important component of continuous VET is vocational training of employees of enterprises, especially on-the-job training. It is confirmed by the results of the correlation analysis made within the study which showed a significant positive correlation between the intensity of on-the-job training, competitiveness of the country and development of knowledge economy for various European countries. The advantages of this type of training are due to its purely practical focus and minimization of the amount of time that passes between the moment of acquiring knowledge and its implementation in practice.

Given the limited opportunities for provision of additional financial resources for vocational training of workers, the establishment of systems of organisational knowledge at enterprises may be the urgent solution of this problem. It involves, first of all, the change of management philosophy of formation, distribution, exchange, accumulation of existing data, knowledge and information in the organisation. The development of the system of organisational knowledge may become a new way of designing professional competencies as the basis for development of organisational competencies. Formation and development of such systems by Ukrainian economic actors will contribute to the formation of knowledge economy in Ukraine.

\section{References}

Beztelesna, L. I. (2012). Professional development of human resources in Ukraine: tendencies and perspectives. Problems of rational using of social economic and natural recourse potential of the region: financial politics and investments: collection of scientific papers. Visnyk NUVGP, 1, 170-179.

Buckman, R. (2004). Building a Knowledge-Driven Organization. N.Y.: McGraw-Hill.

Buiskool, B. J., Van Lakerveld, J., \& Broek, S. (2009). Educators at Work in two Sectors of Adult and Vocational Education: An overview of two European Research projects. European Journal of Education, 44(2), 145-162. http://dx.doi.org/10.1111/j.1465-3435.2009.01378.x

Boutsiouki, S. (2014). Policy transformations and institutional interventions regarding VET in an employment-oriented European Union. Review of European Studies, 6(1), 201-217. http://dx.doi.org/10.5539/res.v6n1p201 
Cabinet of Ministers of Ukraine. (2014). On approval of the issuance of vouchers to maintain the competitiveness of persons in the labor market: Resolution of the Cabinet of Ministers of Ukraine from 20.03.2013 № 207. Retrieved from http://zakon2.rada.gov.ua/laws/show/207-2013-\%D0\%BF

Cabinet of Ministers of Ukraine. (2013). On approval of the confirmation of the results of the informal vocational training for people working professions: Resolution of the Cabinet of Ministers of Ukraine from 15.05.2013 № 340. Retrieved from http://zakon2.rada.gov.ua/laws/show/340-2013-\%D0\%BF

Cedefop. (2010). Employer-provided vocational training in Europe. Evaluation and interpretation of the third continuing vocational training survey. Research Paper. Luxembourg: Publications Office of the European Union. Retrieved from http://www.cedefop.europa.eu/files/5502_en.pdf

Cedefop. (2013). On the way to 2020: data for vocational education and training policies. Country statistical overviews. Luxembourg: Publications Office of the European Union. Retrieved from http://www.cedefop.europa.eu/node/11920\#bycountry

Cedefop. (2015). VET in Europe-Country reports. Retrieved from http://www.cedefop.europa.eu/en/events-and-projects/networks/refernet/vet-in-europe-country-reports

Chirkina, S. E. (2015). Adult' meaming-making during vocational training. Review of European Studies, 7(4), 128-132. http://dx.doi.org/10.5539/res.v7n4p128

Commission of the European Communities. (2000). A Memorandum on lifelong learning. Commission Stuff Working Paper. Brussels: Commission of the European Communities. Retrieved from http://tvu.acs.si/dokumenti/LLLmemorandum_Oct2000.pdf

Department of Trade \& Industry of Great Britain. (1998). Our Competitive Future: Building the Knowledge Driven Economy. London: Stationery Office Books. Retrieved from http://webarchive.nationalarchives.gov.uk/20070603164510/http://www.dti.gov.uk/comp/competitive/wh_ch 1_1.htm

Dovbii, I. (2009). Personnel training in the system of bank crediting of innovation activity. Kadrovik. Kadrovyi management, 11, 63-68.

Eurofound. (2015). European Working Conditions Surveys. Retrieved from http://eurofound.europa.eu/europeanworking-conditions-surveys-ewcs

Eurostat. (2015). Adult Education Survey. Retrieved from http://ec.europa.eu/eurostat/web/microdata/adult_education_survey.

Eurostat. (2010). Continuing Vocational Training Survey. Retrieved from http://ec.europa.eu/eurostat/web/microdata/continuing-vocational-training-survey

Eurostat. (2015). European Union Labour Force Survey. Retrieved from $\mathrm{http} / / /$ ec.europa.eu/eurostat/web/microdata/european-union-labour-force-survey

Eurostat. (2015). Labour Market Statistics. Labour Cost Surveys. Retrieved from http://ec.europa.eu/eurostat/web/labour-market/labour-costs

Eurostat. (2015). Lifelong Learning Eurostat Database. Retrieved from http://ec.europa.eu/eurostat/data/database

Eurostat. (2015). Science and technology statistics. Community Innovation Survey. Retrieved from http://ec.europa.eu/eurostat/web/microdata/community_innovation_survey.

Figel, J. (2009). A life of learning for all. Adults Learning. National Institute of Adults Continuing Education, 20(5), 16-17.

Garvin, D. A. (2003). Building a learning organization. Harvard Business Review, 71 (4), 78-84.

Hin, A. (2007). TRIZ-education: What to teach children. TRIZ-Conference-2007. Retrieved from http://www.metodolog.ru/01133/01133.html\#r

Hnibidenko, I. F. (2008). Market of educational services and labour market: Cooperation and impact on professional training and professional orientation of the population of Ukraine. Labour market and employment of population. Retrieved from http://www.nbuv.gov.ua/Soc_Gum/ Rpzn/2008_3/08giftpn.pdf

Holubkin, V. N. (2006). Three approaches to knowledge management during transfomations of modern economy. Problems of forecasting, 6, 102-113. 
Huber, G. P. (1991). Organizational learning: The contributing processes and the literatures. Organization Science, 2(1), 39-43. http://dx.doi.org/10.1287/orsc.2.1.88

Knoema, E. (2015). World Data Atlas. Retrieved from http://knoema.com/atlas/sources/Eurostat?regionId=NO

Makarova, E. V. (2014). Education in the Modernized Society: Goals and Priorities for Ukraine. Demography and Social Economy, 2(21), 37-47.

Mulder, M., Weigel, T., \& Collins, K. (2007). The concept of competence in the development of vocational education and training in selected EU member states: A critical analysis. Journal of Vocational Education \& Training, 59(1), 67-88.

Nemtzev, A. D., \& Mahmudova, I. N. (2012). Technique of the economic estimation of necessity and expediency of development of the personnel. Vestnik of Volzhskyi University named after V. N. Tatishev, 1(25), 99-110.

Organisation for Economic Co-operation and Development. (1996). The knowledge-based economy. Retrieved from http://www.oecd.org/sti/sci-tech/1913021.pdf

Savchenko, V. A. (2012). Professional training of economic active population of age older than 45 years. Social-Labour Relationships: Theory and Practice: Collection of Scientific Papers, 1(3), 41-48.

Senge, P., Lucas, T., \& Smith, B. (2000). Schools That Learn. A Fifth Discipline Fieldbook for Educators, Parents, and Everyone Who Cares About Education. New York : Doubleday/Currency.

The State Service of Statistics of Ukraine. (2011). Costs of Labourforce: Statistical bulletin. Kyiv: The State Service of Statistics of Ukraine.

The State Service of Statistics of Ukraine. (2011). Labour of Ukraine in 2010 year: Statistical yearbook. Kyiv: The State Service of Statistics of Ukraine.

Tsang, E. W. K. (1997). Organizational Learning and the Learning Organization: A Dichotomy Between Descriptive and Prescriptive Research. Human Relations, 50(1), 73-89. http://dx.doi.org/10.1023/A:1016905516867

UNESCO-UNEVOC. (2015). World TVET Database-Country Profiles. Retrieved from http://www.unevoc.unesco.org/go.php?q=World+TVET+Database

Verkhovna Rada of Ukraine. (2015). The Labor Code of Ukraine from 10.12.1971 № 322-VIII. Revision from 08.02.2015. Retrieved from http://zakon1.rada.gov.ua/laws/show/\%D0\%BA\%D0\%BE\%D0\%B4\%D0\%B5\%D0\%BA\%D1\%81\%20\%D0 $\% \mathrm{~B} 7 \% \mathrm{D} 0 \% \mathrm{~B} 0 \% \mathrm{D} 0 \% \mathrm{BA} \% \mathrm{D} 0 \% \mathrm{BE} \% \mathrm{D} 0 \% \mathrm{BD} \% \mathrm{D} 1 \% 96 \% \mathrm{D} 0 \% \mathrm{~B} 2 \% 20 \% \mathrm{D} 0 \% \mathrm{BF} \% \mathrm{D} 1 \% 80 \% \mathrm{D} 0 \% \mathrm{BE} \% 20 \%$ D0\%BF\%D1\%80\%D0\%B0\%D1\%86\%D1\%8E

Verkhovna Rada of Ukraine. (2015). On Education: Law of Ukraine from 23.05.1991 № 1060-XII. Revision from 01.01.2015. Retrieved from http://zakon1.rada.gov.ua/laws/show/\%D0\%BF\%D1\%80\%D0\%BE\%20\% D0\%BE\%D1\%81\%D0\%B2\%D1\%96\%D1\%82\%D1\%83

Verkhovna Rada of Ukraine. (2015). On Employment of Population: Law of Ukraine from 05.07.2012 № 5067-VI. Revision from 01.01.2015. Retrieved from http://zakon1.rada.gov.ua/laws/show/5067-17

Verkhovna Rada of Ukraine. (2013). On Professional Development of Employees: Law of Ukraine from 12.01.2012 № 4312-VI. Revision from 01.01.2013. Retrieved from http://zakon1.rada.gov.ua/laws/show/\%D0\%BF\%D1\%80\%D0\%BE\%20\% D0\%BF\%D1\%80\%D0\%BE\%D1\%84\%D0\%B5\%D1\%81\%D1\%96\%D0\%B9\%D0\%BD\%D0\%B8\%D0\%B9 $\% 20 \% \mathrm{D} 1 \% 80 \% \mathrm{D} 0 \% \mathrm{BE} \% \mathrm{D} 0 \% \mathrm{~B} 7 \% \mathrm{D} 0 \% \mathrm{~B} 2 \% \mathrm{D} 0 \% \mathrm{~B} 8 \% \mathrm{D} 1 \% 82 \% \mathrm{D} 0 \% \mathrm{BE} \% \mathrm{D} 0 \% \mathrm{BA} \% 20 \% \mathrm{D} 0 \% \mathrm{BF} \% \mathrm{D} 1 \%$ 80\%D0\%B0\%D1\%86\%D1\%96\%D0\%B2\%D0\%BD\%D0\%B8\%D0\%BA\%D1\%96\%D0\%B2

Verkhovna Rada of Ukraine. (2015). On Vocational Education: Law of Ukraine from 10.02.1998 № 103/98-BP. Revision from $01.01 .2015 . \quad$ Retrieved from http://zakon1.rada.gov.ua/laws/show/\%D0\%BF\%D1\%80\%D0\%BE\%20\%D0\%BF\%D1\%80\%D0\%BE\%D1 $\% 84 \% \mathrm{D} 0 \% \mathrm{~B} 5 \% \mathrm{D} 1 \% 81 \% \mathrm{D} 1 \% 96 \% \mathrm{D} 0 \% \mathrm{~B} 9 \% \mathrm{D} 0 \% \mathrm{BD} \% \mathrm{D} 0 \% \mathrm{BE} \% \mathrm{D} 1 \% 82 \% \mathrm{D} 0 \% \mathrm{~B} 5 \% \mathrm{D} 1 \% 85 \% \mathrm{D} 0 \% \mathrm{BD} \%$ D1\%96\%D1\% 87\%D0\%BD\%D1\%83\%20\%D0\%BE\%D1\%81\%D0\%B2\%D1\%96\%D1\%82\%D1\%83

World Bank. (2015). GDP per capita. The World Bank Indicators. Retrieved from http://data.worldbank.org/indicator/NY.GDP.PCAP.CD

World Bank Group. (2015). Enterprise surveys. Survey methodology. Retrieved from http://www.enterprisesurveys.org/methodology 
World Bank Group. (2012). Knowledge Assessment Methodology 2012. Knowledge For Development (K4D). Retrieved from http://web.worldbank.org/WBSITE/EXTERNAL/WBI/WBIPROGRAMS/KFDLP /EXTUNIKAM/0,,menuPK:1414738 pagePK:64168427 piPK:64168435 theSitePK:1414721,00.html

World Bank Group. (2012). KEI and KI Indexes 2012. Knowledge For Development (K4D). Retrieved from http://info.worldbank.org

World Bank Institute. (2008). Measuring Knowledge in the World's Economies. Knowledge Assessment Methodology and Knowledge Economy Index. Knowledge Development Program. Retrieved from http://siteresources.worldbank.org/INTUNIKAM/Resources/KAM_v4.pdf

World Economic Forum. (2014). The Global Competitiveness Index Historical Dataset. Retrieved from http://www3.weforum.org/docs/GCR2014.../GCI_Dataset_2006-07-2014-15.xlsx

Zhdankin, N. (2009). How to make an effective manager from a foreman. Management of Personnel, 3. Retrieved from http://www.top-personal.ru/issue.html?1905

\section{Copyrights}

Copyright for this article is retained by the author(s), with first publication rights granted to the journal.

This is an open-access article distributed under the terms and conditions of the Creative Commons Attribution license (http://creativecommons.org/licenses/by/3.0/). 